\title{
Myositis facilitates preclinical accumulation of pathological prion protein in muscle
}

\author{
Melanie Neumann" ${ }^{1}$ Susanne Krasemann', Katharina Schröck ${ }^{1}$, Karin Steinbach² and Markus Glatzel ${ }^{1 *}$
}

\begin{abstract}
Background: In human and animal prion diseases, pathological prion protein, $\operatorname{PrP}^{\mathrm{Sc}}$, as well as prion infectivity is mainly found in the central nervous system, but also in lymphoid organs and muscle. Pathophysiology of prion colonization of lymphoid organs has been studied intensively, yet how myositis influences prion accumulation in muscle is unknown.

Result: We have investigated the influence of myositis on $\mathrm{PrP}^{\mathrm{Sc}}$ accumulation and prion infectivity in two distinct mouse models of experimental autoimmune myositis. Furthermore, we have addressed the relevance of $\operatorname{Pr} \mathrm{P}^{C}$ expression in the lymphoreticular system in myositis by generating bone marrow chimeras.

Here we show that myositis positively influences muscular $\operatorname{PrP}^{S c}$ accumulation at preclinical time points and that $\mathrm{PrP}^{\mathrm{C}}$-expression in the lymphoid system is critical for this. In muscle, $\mathrm{PrP}^{\mathrm{SC}}$ and prion infectivity are uncoupled with detectable $\operatorname{PrP}^{\mathrm{Sc}}$ but no prion infectivity at preclinical time points. Muscle has an intrinsically high ability to clear $\mathrm{PrP}^{\mathrm{SC}}$ once myositis has ceased, possibly involving autophagy.

Conclusion: Our findings provide new insights into the pathophysiology of prion colonization in muscle pointing out that myositis leads to enhanced prion colonization of muscle in subclinical prion disease.
\end{abstract}

\section{Background}

Prion diseases are characterized by the accumulation of misfolded prion protein $\left(\mathrm{PrP}^{\mathrm{Sc}}\right)$, a posttranslationally modified form of the host-encoded prion protein $\left(\mathrm{PrP}^{\mathrm{C}}\right)$ [1]. Accumulation of $\mathrm{PrP}^{\mathrm{Sc}}$ correlates with neurodegeneration, and $\mathrm{PrP}^{\mathrm{Sc}}$ represents an essential part of the infectious agent causing prion disease [2-4]. Prion diseases occur in animals as well as in humans and are transmissible within and more rarely between mammalian species. Prion diseases in animals include scrapie in sheep and goat [5], chronic wasting disease in elk and deer [6], and bovine spongiform encephalopathy in cattle [7]. Among the human prion diseases, three distinct etiologies are defined: they either arise sporadically as in sporadic CreutzfeldtJakob disease (sCJD), as autosomal dominantly inherited diseases as in genetic Creutzfeldt-Jakob disease (gCJD) or as acquired conditions in iatrogenic or variant CreutzfeldtJakob disease (iCJD, vCJD) [8,9].

\footnotetext{
*Correspondence: m.glatzel@uke.de

'Institute of Neuropathology, University Medical Center Hamburg-Eppendorf, Hamburg 20246, Germany

Full list of author information is available at the end of the article
}

In prion diseases, accumulation of $\operatorname{PrP}^{\mathrm{Sc}}$ and prion infectivity is not confined to the nervous system. $\operatorname{PrP}^{\mathrm{Sc}}$ and prion infectivity are inevitably detectable in the lymphoreticular system (LRS) or in the skeletal muscle of terminally diseased individuals or animals [10-14]. In the subclinical phase of disease, the situation differs. Here $\operatorname{PrP}^{\mathrm{Sc}}$ and prion infectivity are readily detectable in the LRS in the majority of instances, whereas prion accumulation in muscle occurs to a lesser extent both quantitatively and qualitatively [15-18].

Our knowledge on the pathophysiology of $\mathrm{PrP}^{\mathrm{Sc}}$ accumulation between LRS and muscle differs as well. For prion colonization of the LRS, the molecular events have been worked out in great detail. Here, follicular dendritic cells (FDCs) residing in germinal centers of lymphoid follicles accumulate $\operatorname{PrP}^{\mathrm{Sc}}$ before prions find their way to the central nervous system via peripheral nerves [19-21].

$\operatorname{PrP}^{\mathrm{C}}$ expression in muscle has been studied and it could be shown that myocytes as well as muscle macrophages express $\operatorname{PrP}^{\mathrm{C}}[22]$ and that the expression in muscle is highly regulated and fibre-type specific [23]. Overexpression of $\operatorname{PrP}^{C}$ in muscle leads to a myopathy and a wide range of myopathies are characterized by 
increased $\operatorname{PrP}^{\mathrm{C}}$-levels [23-27]. However, in muscle much less is known regarding molecular determinants of $\mathrm{PrP}^{\mathrm{Sc}}$ accumulation. $\operatorname{PrP}^{\mathrm{Sc}}$ accumulation is muscle-type specific with hind limbs showing higher $\operatorname{PrP}^{\mathrm{Sc}}$ content than fore limb muscles [28]. Thus, the molecular mechanisms underlying accumulation of $\mathrm{PrP}^{\mathrm{Sc}}$ and prion infectivity in skeletal muscle are poorly understood. Case studies from patients with myositis and prion disease suggest that inflammation may promote $\operatorname{PrP}^{\mathrm{Sc}}$ accumulation [29]. In fact, recent data indicate that ectopic follicular inflammation is able to support prion accumulation even in non-lymphoid tissue [30]. On the other hand, peripheral nerves or muscle spindles or myocytes, have been shown to accumulate $\mathrm{PrP}^{\mathrm{Sc}}$ even in the absence of inflammation [13,15,31].

Here, we show that $\operatorname{PrP}^{\mathrm{Sc}}$ accumulation in skeletal muscle of mice was enhanced upon induction of experimental autoimmune myositis (EAM) in early subclinical prion disease. Our data suggest that accumulation of $\mathrm{PrP}^{\mathrm{Sc}}$ correlates with elevated levels of $\mathrm{PrP}^{\mathrm{C}}$ at the peak of myositis originating from infiltrating lymphocytes. Once myositis ceased, $\operatorname{PrP}^{\mathrm{Sc}}$ was rapidly cleared from muscle most likely by autophagy which is upregulated in muscle compared to spleen and brain. Accumulation of $\mathrm{PrP}^{\mathrm{Sc}}$ in inflamed muscle required presence of $\operatorname{PrP}^{\mathrm{C}}$ on the LRS. Interestingly, titers of infectious prions as measured by bioassay were unchanged between the myositis and the control cohort pointing to an uncoupling of $\mathrm{PrP}^{\mathrm{Sc}}$ loads and titers of infectious prions in our experimental model.

\section{Methods}

\section{Animals}

Five to six weeks old SJL/J and C57Bl/6 mice were purchased from Charles River Laboratory (Sulzfeld, Germany). Prion protein-deficient mice $\left(\operatorname{Prnp}^{0 / 0}\right)$ [32] were bred in house. Mice were sacrificed in groups of 4 animals at day 35, day 60, and day 90 after inoculation with Rocky Mountain Laboratory (RML) prions or when clinical signs of terminal prion disease (tail rigidity, weight loss, ataxia, and roughened fur) occurred. All animal procedures were performed in accordance with the institutional guidelines from the animal facility of the University Medical Center Hamburg-Eppendorf.

\section{Generation of bone marrow chimeras}

$\mathrm{C} 57 \mathrm{Bl} / 6$ mice were irradiated with a dosage of 8 Gy with constant 1 Gy/min using a BIOBEAM 2000 Cs-137 chloride gamma irradiator (Eckert \& Ziegler, Berlin, Germany) one day prior to bone marrow reconstitution. Bone marrow was harvested in serum-free media (DMEM) at $4^{\circ} \mathrm{C}$ from femur and tibia of the hind-legs of Prnp $^{0 / 0}$ and $\mathrm{C} 57 \mathrm{Bl} / 6$ mice using a syringe with a $23 \mathrm{G}$ needle. The cell suspension was transferred to a $100 \mu \mathrm{m}$ strainer and the flow-through was centrifuged at $300 \times \mathrm{g}$ for $10 \mathrm{~min}$ at $4^{\circ} \mathrm{C}$. Cell pellets were solubilised in $1 \mathrm{ml}$ of erythrocytes-lysis-buffer containing $0.15 \mathrm{M} \mathrm{NH} \mathrm{NH}_{4} \mathrm{Cl}$, $10 \mathrm{mM} \mathrm{KHCO}_{3}$, and $0.1 \mathrm{mM} \mathrm{Na} \mathrm{N}_{2}$ EDTA ( $\mathrm{pH}=7.2$ to 7.4) and were then incubated for $5 \mathrm{~min}$ on ice. Afterwards cells were washed with PBS and transferred to a $40 \mu \mathrm{m}$ strainer. The flow-through was directly used for reconstitution. Each mouse was injected intravenously with $300 \mu \mathrm{l}$ of the cell suspension containing about $10^{7}$ bone marrow cells in total and reconstitution efficiency was assessed by FACS analysis (see below).

Induction of an experimental autoimmune myositis (EAM) In order to induce an EAM, SJL/J mice were treated as described before [33]. Briefly, purified myosin from rabbit skeletal muscle $(6.6 \mathrm{mg} / \mathrm{ml}$; Sigma-Aldrich, Munich, Germany) was emulsified with an equal amount of Complete Freund's adjuvant (CFA) (Difco Laboratories, Detroit, USA) with $3.3 \mathrm{mg} / \mathrm{ml}$ Mycobacterium butyricum (Difco Laboratories, Detroit, USA). Mice were anesthetized using a $\mathrm{CO}_{2} / \mathrm{O}_{2}$ mixture and were then immunized subcutaneously with $100 \mu \mathrm{l}$ of the emulsion into four locations (total, $400 \mu \mathrm{l}$ ) on the back on days 0 , 7, and 14 . On day 21 and 54 mice were either sacrificed for histological and FACS analysis or they were inoculated at day 21 with RML prions. In order to introduce an EAM in $\mathrm{C} 57 \mathrm{Bl} / 6$ mice, in addition animals were injected intraperitoneally with $0.5 \mu \mathrm{g}$ Pertussis toxin in PBS at all time points of immunizations.

\section{Inoculations, determination of incubation time and prion titers}

At day 21 mice were anesthetized using an intraperitoneal injection of ketamine $(12 \mathrm{mg} / \mathrm{ml})$ mixed with xylazine $(1.6 \mathrm{mg} / \mathrm{ml})$ with a dosage of $100 \mu \mathrm{l}$ solution per $10 \mathrm{~g}$ bodyweight. Afterwards mice were inoculated intraperitoneally with $100 \mu \mathrm{l}$ PBS containing $6 \operatorname{logLD}_{50}$ units of RML scrapie strain. In order to determine the incubation time to onset of terminal prion disease, mice were kept until the day of onset of terminal clinical signs of prion disease (see above). Incubation time in days starting from the day of scrapie administration until the day of death was determined and plotted against the survival probability in \% in Kaplan-Meier survival curves using SPSS statistic software.

Bioassays to determine titers of prion infectivity were performed on $1 \%$ homogenates of either spleen or muscle tissue. Spleens from one single animal per group and muscle tissues from either 1 animal per group (muscle control samples but day 90 and all chimeras), 2 animals per group (SJL/J mice day 35, day 60 and terminal diseased) or 3 animals per group (SJLJ/ mice day 90) were homogenized in $0.32 \mathrm{M}$ sucrose using a FastPrep FP120 homogenizer (Qbiogene, Cedex, France), 
diluted in 5\% BSA in PBS and centrifuged for $5 \mathrm{~min}$ at $500 \times$ g. $30 \mu \mathrm{l}$ of each supernatant were inoculated intracerebrally into groups of 4 highly prion susceptible tga20 mice [34]. The relationship $y=11.45-0.088^{*} \mathrm{x}$ ( $\mathrm{y}, \log$ $\mathrm{LD}_{50}$ per milliliter of homogenate; $\mathrm{x}$, incubation time in days to terminal disease) was used to calculate prion titers $[35,36]$.

\section{Immunohistochemistry}

Muscle and brain tissues were either frozen in liquid nitrogen-cooled 2-methyl-butan (Sigma Aldrich, Munich, Germany) and cut into $8 \mu \mathrm{m}$ sections with a cryostat (CM1950, Leica, Wetzlar, Germany; see Figures 1a and 2), or were fixed using $3.5 \%$ of formaldehyde solution buffered according to Lillie for 15 hrs (see Figures 3c, 4c and 5b). If appropriate, tissues were prion-inactivated using 98\% formic acid for $1 \mathrm{hr}$ followed by $3.5 \%$ of formaldehyde solution for at least $12 \mathrm{hrs}$. Tissues were processed to paraffin blocks using an ASP300S dehydration machine (Leica, Wetzlar, Germany) and an EG1160 tissue embedding system (Leica, Wetzlar, Germany). Paraffin blocks were cut into $4 \mu \mathrm{m} \mathrm{sec-}$ tions, which were stained with hematoxylin and eosin following standard laboratory procedures. Sections from frozen tissue were also stained with Elastica-von-Giesson standard staining solutions. For immunohistochemical staining the Ventana Benchmark XT machine (Ventana, Tuscon, Arizona, USA) was used. Briefly, deparaffinised sections were boiled for 30 to $60 \mathrm{~min}$ in $10 \mathrm{mM}$ citrate buffer, $\mathrm{pH}$ 6.0, for antigen retrieval. Primary antibodies were diluted in 5\% goat serum (Dianova Immundiagnostic, Hamburg, Germany), 45\% Tris buffered saline pH 7.6 (TBS) and $0.1 \%$ Triton X-100 in antibody diluent solution (Zytomed, Berlin, Germany). Sections were then incubated with primary antibody for $1 \mathrm{hr}$ (see also Table 1). Antirabbit or anti-goat histofine Simple Stain MAX PO Universal immunoperoxidase polymer (Nichirei Biosciences, Wedel, Germany) were used as secondary antibodies. Detection of secondary antibodies and counter staining was performed with an ultraview universal DAB detection kit from Ventana (Ventana, Tuscon, Arizona, USA) according to the standard settings of the machine. The staining of FDCs was performed according manufactures' instructions. All sections were cover-slipped using TissueTek ${ }^{\odot}$ glove mounting media (Sakura Finetek, Staufen, Germany), and dried in an incubator at $60^{\circ} \mathrm{C}$. Pictures were taken using a light microscope (Axioskop 40, Zeiss, Jena, Germany or Olympus BH-2, Hamburg, Germany) equipped with a digital camera (AxioCam ICc3 Zeiss, Jena Germany).

\section{Sodium phosphotungstic acid (NaPTA) precipitation}

NaPTA precipitation was performed according to a previously, slightly modified method [14,37]. Briefly, $100 \mathrm{mg}$ of frozen tissue was thawed and put into $900 \mu \mathrm{l}$ of dissociation buffer containing $25 \mathrm{mM}$ HEPES ( $\mathrm{pH}$ 7.2),
0.3 M sucrose and 53.6 $\mu$ g Liberase Blendzyme 2 (Roche, Penzberg, Germany). Samples were incubated for $30 \mathrm{~min}$ at $37^{\circ} \mathrm{C}$ with a ribolyzing step performed every $10 \mathrm{~min}$, until completely homogenized. To each $500 \mu \mathrm{l}$ of $10 \%(\mathrm{w} / \mathrm{v})$ tissue homogenates an equal volume of $4 \%$ $(\mathrm{w} / \mathrm{v})$ sarkosyl-PBS was added, vortexed, and incubated for $10 \mathrm{~min}$ at $37^{\circ} \mathrm{C}$ with constant agitation. $50 \mathrm{U} / \mathrm{ml}$ of benzonase (Novagen, Darmstadt, Germany) and $1 \mathrm{mM}$ $\mathrm{MgCl}_{2}$ were added, and incubated at $37^{\circ} \mathrm{C}$ for $30 \mathrm{~min}$ with vigorous agitation. Afterwards, $81.3 \mu \mathrm{l}$ of a prewarmed (to $37^{\circ} \mathrm{C}$ ) $4 \%\left(\mathrm{w} / \mathrm{v}\right.$ ) $\mathrm{NaPTA} / 170 \mathrm{mM} \mathrm{MgCl}_{2}$ solution ( $\mathrm{pH}$ 7.4) was added, vortexed, and incubated with vigorous agitation for $30 \mathrm{~min}$ at $37^{\circ} \mathrm{C}$. Samples were then centrifuged at $16,000 \times \mathrm{g}$ for $30 \mathrm{~min}$, after which supernatants were carefully removed and the remaining pellets resuspended in $22.5 \mu \mathrm{l}$ of $0.1 \%$ sarkosyl-PBS. For detection of $\mathrm{PrP}^{\mathrm{Sc}}$ only, samples were digested with proteinase K (Invitrogen, Karlsruhe, Germany) for $60 \mathrm{~min}$ at $37^{\circ} \mathrm{C}$ with a final concentration of $20 \mu \mathrm{g} / \mathrm{ml}$. Since $\operatorname{PrP}^{\mathrm{C}}$ is proteinase $\mathrm{K}$ sensitive it is digested completely after this treatment, whereas $\mathrm{PrP}^{\mathrm{Sc}}$ is proteinase $\mathrm{K}$ resistant and therefore is still detectable. Digestion was stopped by adding CVL-sample buffer (1\% (w/v) SDS; $25 \mathrm{mM}$ Tris/HCl, pH 7.4; 2,5\% (v/v) $\beta$-mercaptoethanol; $1.5 \%$ $(\mathrm{w} / \mathrm{v})$ sucrose; $0.02 \%(\mathrm{w} / \mathrm{v})$ brome-phenol-blue) and boiling for $10 \mathrm{~min}$ prior to Western blot analysis. As positive control RML 5.0 standard inoculum brain homogenate (RML) was spiked into uninfected tissue and digested as described.

\section{Western blots}

Frozen tissues were thawed, homogenized and $\sim 50 \mu \mathrm{g}$ of total protein were separated by SDS-PAGE on a $12 \%$ SDSPAGE gel, transferred to PVDF membranes (Biorad, Munich, Germany) at $400 \mathrm{~mA}$ for $1 \mathrm{hr}$ in a wet-blot chamber (Biorad, Munich, Germany), and blocked for $1 \mathrm{hr}$ at room temperature in $5 \%(\mathrm{w} / \mathrm{v})$ milk powder in PBS containing $0.1 \%$ of Tween 20. Membranes were incubated overnight at $4^{\circ} \mathrm{C}$ using anti-PrP antibody POM1 or for two days using the anti-LC3 antibody, both in blocking buffer (see also Table 1). After incubation for 1 hour at room temperature with an HRP-conjugated anti-mouse secondary antibody (Promega GmbH, Mannheim, Germany, 1:5000 in blocking buffer), proteins were detected using ECL femto reagent (Pierce, Rockford USA). Samples were recorded and chemiluminescence signals were quantified using a chemiluminescence reader (Biorad, Munich, Germany). Detection of beta-actin (Sigma-Aldrich, Seelze, Germany) served as an internal loading control.

\section{FACS analysis of blood samples}

Two drops of blood, drawn by submandibular puncture were transferred into $5 \mathrm{ml}$ of FACS buffer containing 2\% (v/v) FCS, 0.01 M EDTA (pH 8) and 0.1\% (w/v) $\mathrm{NaN}_{3}$ in 


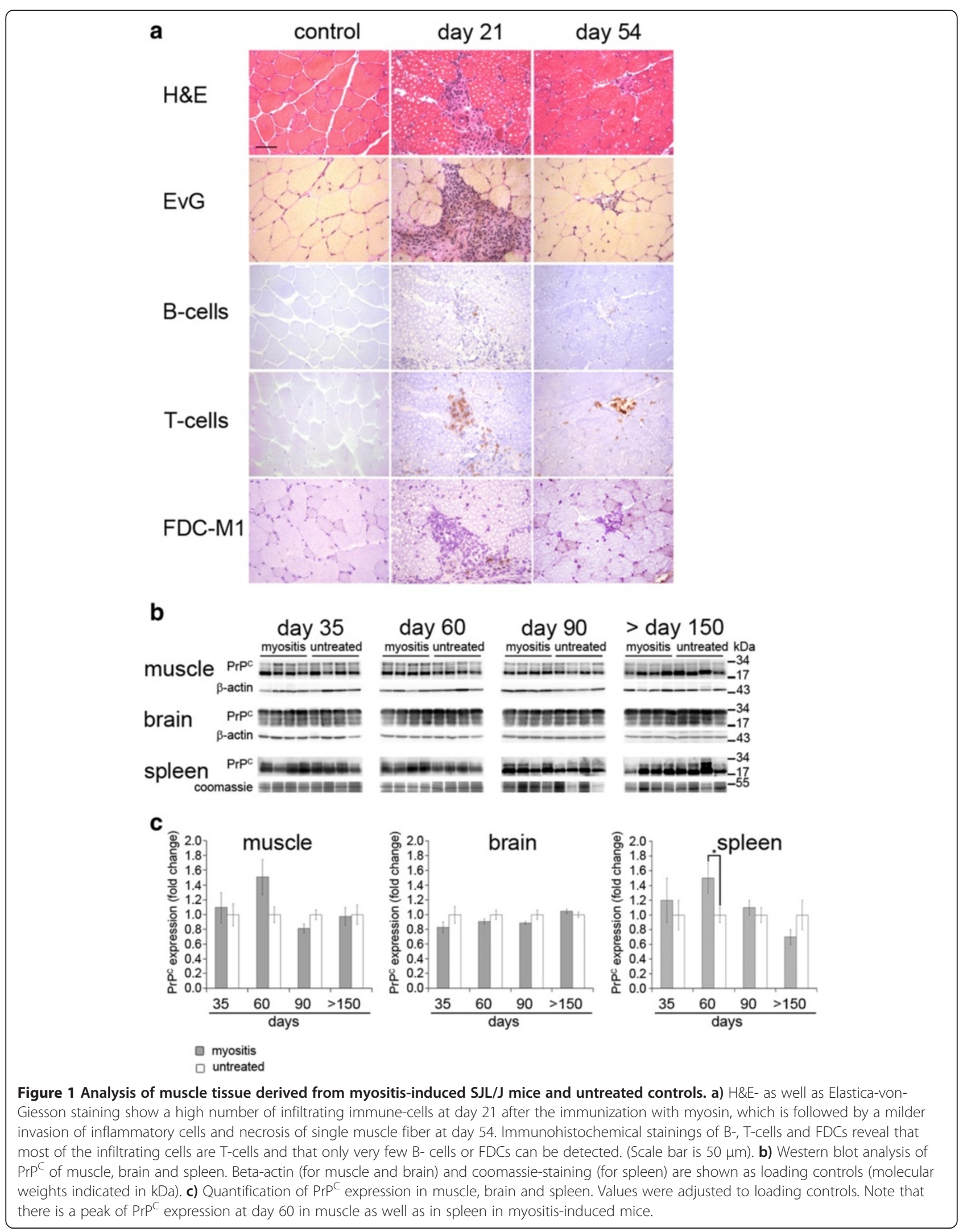




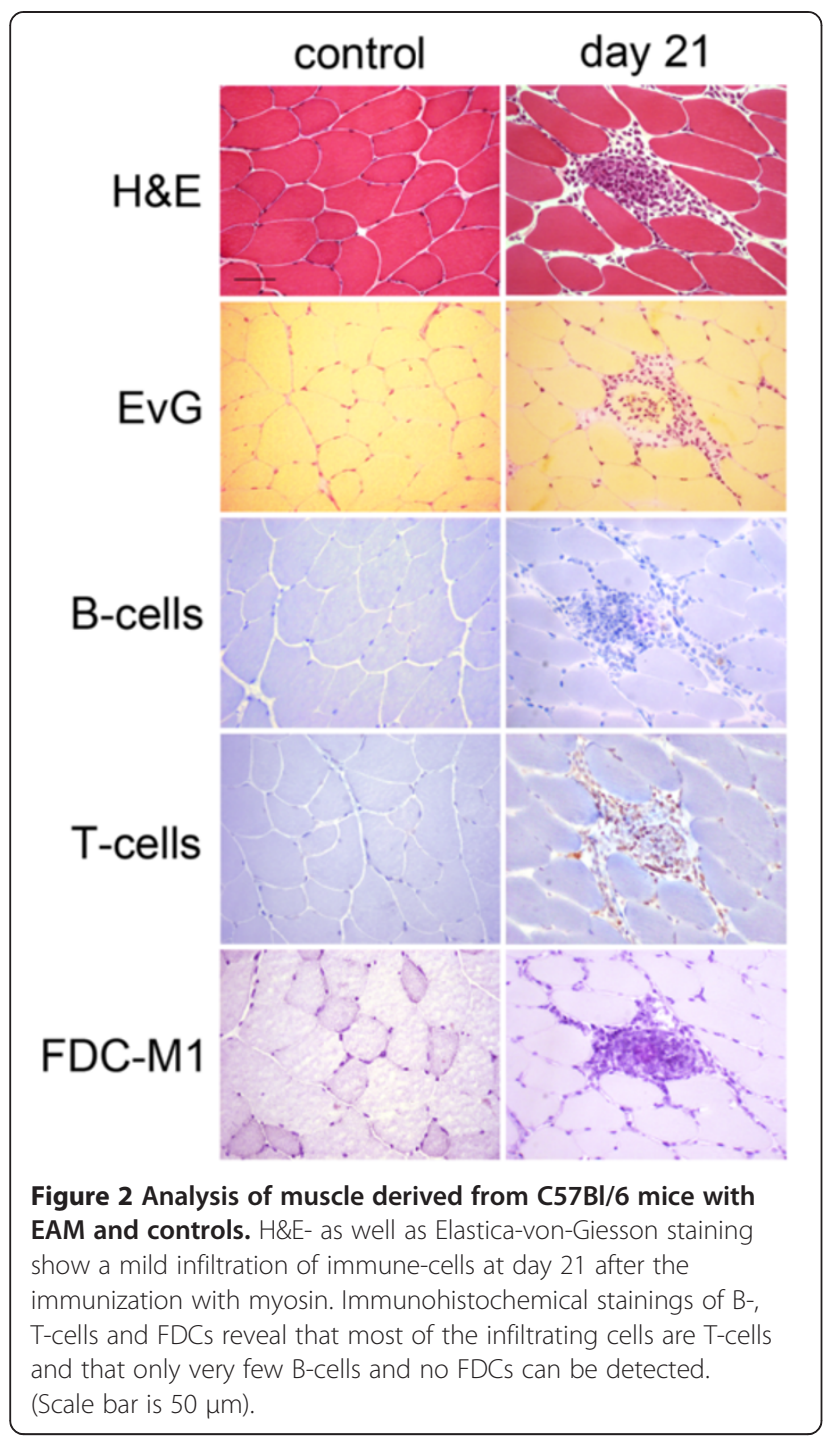

PBS. After centrifugation of the samples for $10 \mathrm{~min}$ at $1000 \mathrm{rpm}$ supernatants were discharged and $100 \mu \mathrm{l}$ of primary antibody (biotinylated 6H4, Prionics, PlaneggMartinsried, Germany) diluted 1:100 in FACS buffer was added to the pellets and incubated at $4^{\circ} \mathrm{C}$ for $30 \mathrm{~min}$. Afterwards samples were washed and incubated with fluorochrome-labelled streptavidin diluted 1:100 in FACS buffer at $4^{\circ} \mathrm{C}$ for $30 \mathrm{~min}$. After another washing step samples were counterstained with an antibody against T-cells (PE-anti-CD3 ( $2 \mu \mathrm{l}$ per sample)) by incubating at $4^{\circ} \mathrm{C}$ for $30 \mathrm{~min}$. Following rigorous washing steps, samples were resuspended in $0.5 \mathrm{ml}$ of FACS buffer and were analyzed using a LSRII FACS machine (BD Bioscience, Heidelberg, Germany).

\section{FACS analysis of muscle samples}

Quadriceps femoris muscles of immunized mice were dissected, minced and put into $5 \mathrm{ml}$ of digestion buffer before incubation at $37^{\circ} \mathrm{C}$ for $30 \mathrm{~min}$. Then, cooled $\left(4^{\circ} \mathrm{C}\right)$ samples were washed and passed through a $100 \mu \mathrm{m}$ cell strainer as well as through a $30 \mu \mathrm{m}$ pre-separation filter (Miltenyi Biotec, Bergisch Gladbach, Germany). The flow-through was resuspended in $2.5 \mathrm{ml}$ of a $30 \%$ Percoll solution and underlayed with $2 \mathrm{ml}$ of a 78\% Percoll solution before centrifugation for $30 \mathrm{~min}$ at $2500 \mathrm{rpm}$. Cells lying at the interface of the gradient were removed and washed several times with FACS buffer. In order to block Fc receptors before FACS analysis, pellets were incubated for $10 \mathrm{~min}$ in $50 \mu \mathrm{l}$ of FACS buffer containing $1 \mu \mathrm{l}$ of Fc-block (eBioscience, Frankfurt, Germany). After washing cells were stained for $1 \mathrm{hr}$ using $10 \mu \mathrm{l}$ of each of the following antibodies: Gr1-FITC, NU1.1-PE, B220PECP-Cy5.5, CD11c-PECy7, CD11b-APC, CD45-APCCy7, and CD3-PaBkuc. After washing cells were resuspended in $400 \mu \mathrm{l}$ of FACS buffer and were analyzed using a LSRII FACS machine (BD Bioscience, Heidelberg, Germany).

\section{Statistical analysis}

In all experiments, mean $+/-$ SEM is reported. Statistical comparisons among groups were determined using Student's $t$ test.

\section{Results}

Induction of experimental autoimmune myositis (EAM) in $\mathrm{SJ} / \mathrm{J}$ mice

EAM was induced by subcutaneous injection of myosin and CFA at days 0, 7 and 14. On day 21 and 54, quadriceps femoris muscles of hind-legs were analyzed by FACS or histology (Figure 6). As shown in Table 2, FACS revealed T-cell dominated myositis (50.3 and $21.3 \%$ of all infiltrating cells at day 21 and 54 were CD3-positive; 17.3 and $1.4 \%$ of all infiltrating cells at day 21 and 54 were B220-positive) in EAM mice when compared to controls (5.6\% of all infiltrating cells were CD3-positive; $1.2 \%$ of all infiltrating cells were B220-positive). Neutrophil granulocytes and other lymphocytes were not changed between EAM and controls. Up-regulation of T- and B-cells in EAM could be confirmed histologically (Figure 1a), where we found prominent lymphocytic infiltrates as early as day 21 . Immunohistochemical staining with antibodies against CD3 for T-cells, B220 for B-cells and milk fat globule protein-epidermal growth factor-8 (MFG-E8) for FDCs demonstrated high numbers of T- and B-cells as well occasional MFG-E8positive cells in EAM when compared to control tissue. Less pronounced infiltrates of T- and B-cells, but no MFG-E8positive cells could be detected at day 54 after immunization. At both time points, morphological signs of chronic myositis such as necrotic muscle fibers and fibrosis were found in EAM but not in controls (Figure 1a). Interestingly, myositis did not lead to a reduction in muscle strength as demonstrated by hanging wire test (Additional file 1: Figure S1). For further analysis, prion inoculations 

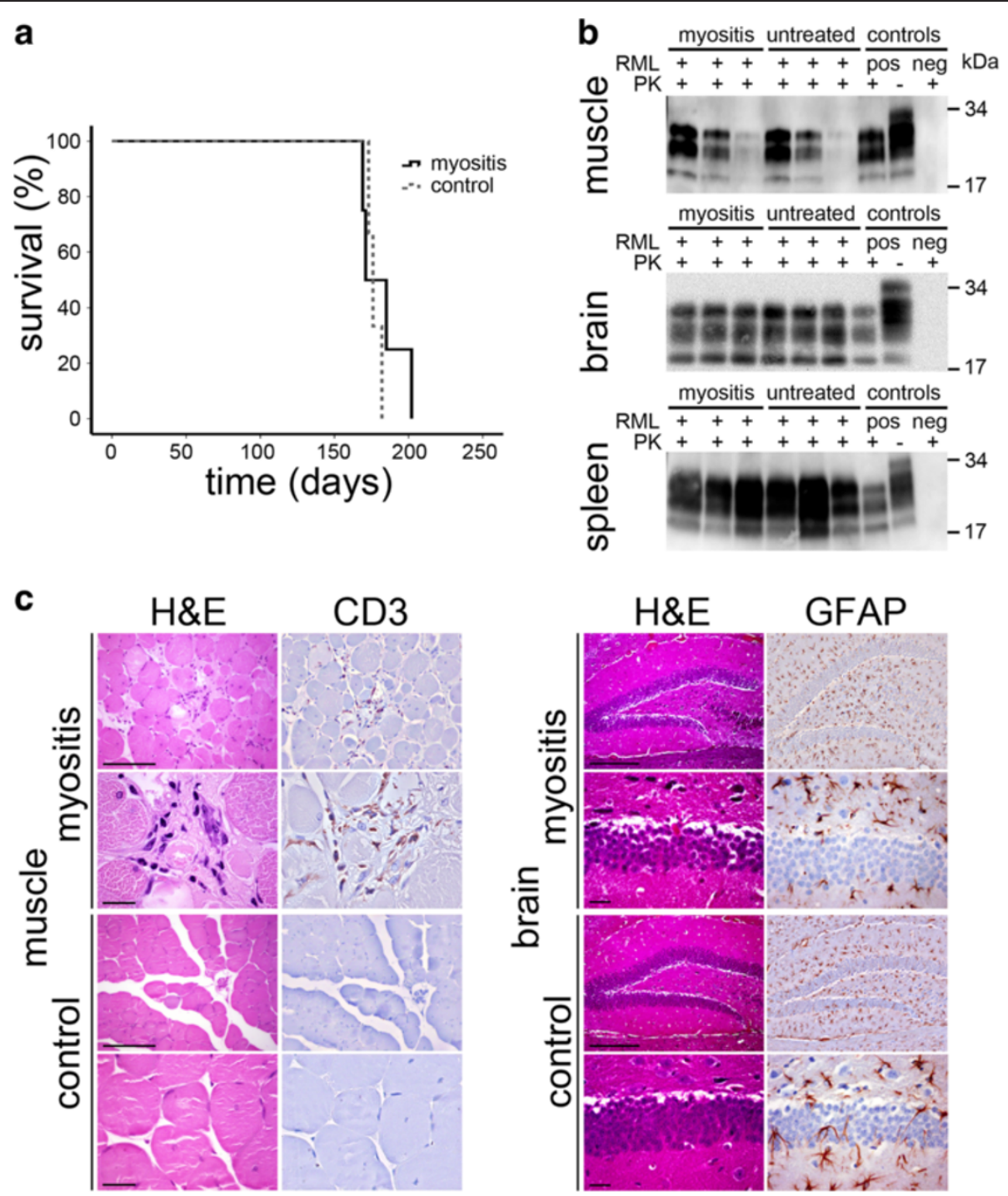

Figure 3 Analysis of terminal diseased EAM / control mice. a) Kaplan-Meier curve showing no differences in survival probability in prion inoculated EAM-mice when compared to controls. b) Western blots of muscle, brain and spleen of terminal sick EAM / control mice. PrPSc loads are variable without significant differences between groups. As positive control, brain homogenate from a terminally diseased wild type mouse is loaded with and without PK-digestion. As negative control brain homogenate from a healthy wild type mouse is loaded with PK-digestion (molecular weights indicated in $\mathrm{kDa}$ ). c) $\mathrm{H} \& \mathrm{E}$ as well as immunohistochemical staining for T-cell marker CD3 show signs of myositis in the muscle tissue only in EAM mice but not controls. Nevertheless, in brain tissue in both cohorts a pronounced gliosis could be detected by H\&E and immunohistochemical staining for astrocyte marker GFAP (Scale bar is $100 \mu \mathrm{m}$ and $20 \mu \mathrm{m}$ for muscle and $200 \mu \mathrm{m}$ and $20 \mu \mathrm{m}$ for brain).

were performed at peak of inflammation (21 days after the first immunization). For reasons of clarity, day of RML/ sham (CD1 brain homogenate) inoculation was set to day 0, see Figure 6.

\section{EAM leads to enhanced expression of $\operatorname{PrP}^{C}$ in muscle}

To investigate if EAM leads to an up-regulation of $\operatorname{PrP}^{C}$ in muscle, we analyzed muscle tissue for its $\operatorname{PrP}^{\mathrm{C}}$ content by Western blotting and compared data to $\mathrm{PrP}^{\mathrm{C}}$-levels in spleen and brain. As shown in Figure 1, we could detect a slight up-regulation of $\operatorname{PrP}^{\mathrm{C}}$ at day 60 after sham immunization in muscle (Figure 1b,c; $p=0.1$ ). In all other muscle samples we could not find any changes in $\operatorname{PrP}^{\mathrm{C}}$ expression. As expected, brain showed high levels of $\operatorname{PrP}^{C}$ irrespective of EAM (Figure $1 \mathrm{~b}, \mathrm{c}$ ). $\operatorname{PrP}^{\mathrm{C}}$-levels in spleen showed a considerable variation with a peak of $\operatorname{PrP}^{\mathrm{C}}$ expression at day 60 after sham inoculation (Figure 1b,c, $\mathrm{p}=0.04)$.

\section{EAM does not affect incubation time until onset of terminal prion disease}

Having established a reliable EAM-model, we analyzed if EAM changed incubation time until onset of terminal prion disease. For this, we induced EAM and inoculated 


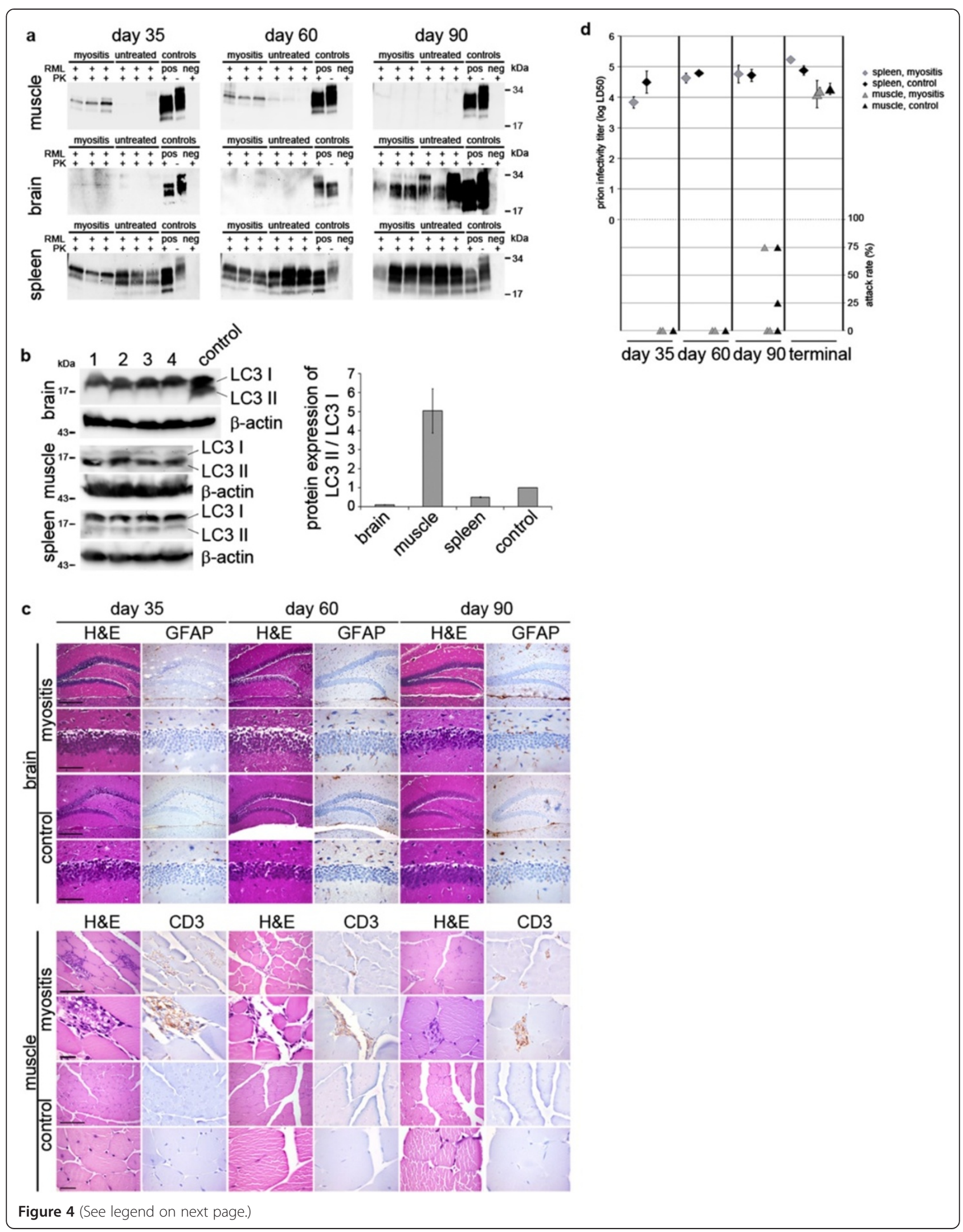


(See figure on previous page.)

Figure 4 Analysis of preclinical prion-inoculated EAM / control mice. a) NaPTA blots (muscle and brain) as well as regular Western blots (spleen) show PrPSc load over time in EAM versus untreated mice. As positive controls for NaPTA blots RML is used as a spike in untreated tissue homogenate and is either PK-digested or undigested. For blot of spleen brain homogenate from a terminally diseased wild type mouse is loaded with and without PK- digestion. As a negative control, PK-digested normal tissue homogenate is used. Note that there are differences in PrPSc loads in muscle at day 35 and 60 in EAM versus control mice. b) Quantifications of western blots of autophagy marker LC3 show elevated amounts of LC3 II versus LC3 I in muscle versus spleen and brain of C57/Bl6 mice at day 0 . ( $n=4$; control = brain homogenate of a cathepsin $D$ knockout mouse). c) H\&E as well as immunohistochemical staining for CD3 show signs of myositis in the muscle tissue only in treated mice in contrast to untreated controls. In brain tissue in both cohorts no gross pathological hallmarks of prion disease could be detected by H\&E and immunohistochemical staining for GFAP over time (scale bar is $200 \mu \mathrm{m}$ and $20 \mu \mathrm{m}$ for brain and $100 \mu \mathrm{m}$ and $20 \mu \mathrm{m}$ for muscle). d) Bioassays to determine titers of prion infectivity reveal no differences between both prion-inoculated EAM and prion-inoculated control mice.

mice at day 21 after immunization with RML prions or sham. At identical time points, non-immunized SJL/J mice were treated equally as control. There was no difference in incubation times until onset of terminal prion disease between myosin-treated and non-treated mice (Figure 3a). EAM mice came down with disease after $182+/-8$ days and non-immunized mice after $177+/-$ 3 days.

After a proteinase $\mathrm{K}$ digestion of tissue homogenates we could detect presence of variable amounts of $\mathrm{PrP}^{\mathrm{Sc}}$ by Western blot analysis in muscle, brain and spleen with no obvious differences in $\operatorname{PrP}^{\mathrm{Sc}}$ loads and $\operatorname{PrP}^{\mathrm{Sc}}$ glycotypes between EAM and controls (Figure 3b, Additional file 2: Figure S2).

In terminally sick mice, where the peak of active myositis has passed, morphological changes such as necrotic muscle fibers or fibrosis, typical for post-myositic muscles, were observed in EAM mice only (Figure 3c). In brain, spongiform changes and astrogliosis, typical for terminal prion disease were observed in both cohorts at comparable extent (Figure 3c).

\section{EAM leads to transient $\operatorname{PrP}^{\mathrm{Sc}}$ accumulation in muscle in subclinical prion disease}

In order to analyze if EAM leads to changed kinetics of $\mathrm{PrP}^{\mathrm{Sc}}$ accumulation in muscle, we investigated $\mathrm{PrP}^{\mathrm{Sc}}$ loads by NaPTA-precipitation and Western blot analysis after proteinase $\mathrm{K}$ digestion to detect $\operatorname{PrP}^{\mathrm{Sc}}$ at 35, 60 and 90 days post prion challenge (Figure 4a). At 35 as well as at 60 days after prion inoculation, we detected prominent $\mathrm{PrP}^{\mathrm{Sc}}$ accumulation only in EAM mice, whereas we could not detect significant levels of $\mathrm{PrP}^{\mathrm{Sc}}$ in control mice. Interestingly, at 90 days after prion inoculation, none of the muscle samples showed any $\mathrm{PrP}^{\mathrm{Sc}}$ accumulation (Figure $4 \mathrm{a}$ ), whereas at terminal disease, $\operatorname{PrP}^{\mathrm{Sc}}$ accumulation was equally strong in EAM and control mice (Figure $3 \mathrm{~b}$ ). In brain and spleen $\mathrm{PrP}^{\mathrm{Sc}}$ accumulation was not influenced by EAM with high $\mathrm{PrP}^{\mathrm{Sc}}$ contents in spleen at all examined time points and rising $\mathrm{PrP}^{\mathrm{Sc}}$ contents in brain detectable from day 90 onwards (Figure $4 \mathrm{a}$ ).

Since autophagy has been shown to clear $\mathrm{PrP}^{\mathrm{Sc}}$ effectively, we investigated if increased autophagy may help to clear $\mathrm{PrP}^{\mathrm{Sc}}$ in muscle. For this, we determined LC3 levels in $\mathrm{C} 57 / \mathrm{Bl6}$ mice at day 0 in order to monitor if autophagy is per se activated in muscle tissue versus brain and spleen. As shown in Figure 4b, there was a high up regulation of LC3 II, a marker for autophagy, in muscle when compared to brain and spleen.

Histologically, signs of myositis could be observed in muscle of EAM mice, but not in control animals at days 35 and 60. At day 90 only EAM mice showed necrotic muscle fibers and fibrosis, both of which are routinely observed as late signs of myositis (Figure 4c). In brain no obvious pathological changes could be detected at preclinical stages (Figure 4c).

\section{Dissociation of PrP ${ }^{\mathrm{Sc}}$ loads and prion infectivity titers in muscle}

$\mathrm{PrP}^{\mathrm{Sc}}$ is thought to constitute an essential component of prion infectivity. Nevertheless, presence of prion infectivity does not strictly correlate with $\mathrm{PK}$-resistant $\mathrm{PrP}^{\mathrm{Sc}}$ load and protease-sensitive $\mathrm{PrP}^{\mathrm{Sc}}$ species harbor significant amounts of prion infectivity [38]. Thus we assessed prion titers of muscle and spleen by bioassay (Figure $4 \mathrm{c}$ ). Titers of infectious prions in muscle were under the detection limit of the assay at early time points demonstrating partial dissociation of $\mathrm{PrP}^{\mathrm{Sc}}$ loads and prion titer. At day 90, prion titers were around LD50 for both cohorts with one EAM mouse (at day 129) and two control mice (at days 123 and 160) showing signs of prion disease. However, at terminal disease stages high infectivity titers $(4.1 \mathrm{log} \mathrm{LD} 50 / \mathrm{ml}$ of tissue homogenate for EAM, $4.3 \log \mathrm{LD} 50 / \mathrm{ml}$ of tissue homogenate for control) could be measured in muscle. As expected, in spleen high infectivity titers (3.8, 4.6, 4.8 and $5.2 \mathrm{log}$ LD50/ml tissue homogenate for EAM, and 4.5, 4.8, 4.7 and $4.9 \mathrm{log}$ $\mathrm{LD} 50 / \mathrm{ml}$ tissue homogenate for controls) at days 30, 60, 90 , and at terminal disease could be detected irrespective of the presence of EAM.

\section{$\mathrm{PrP}^{\mathrm{SC}}$ accumulation in muscle at early time points requires a $\mathrm{PrP}^{\mathrm{C}}$ expressing lymphoreticular system}

Next, we set out to examine which cell type in muscle tissue is responsible for accumulation of $\operatorname{PrP}^{\mathrm{Sc}}$. Since we could show that elevated $\operatorname{PrP}^{\mathrm{C}}$ levels in muscle occur during peak of myositis (Figure 1c), cells of the hematopoietic 


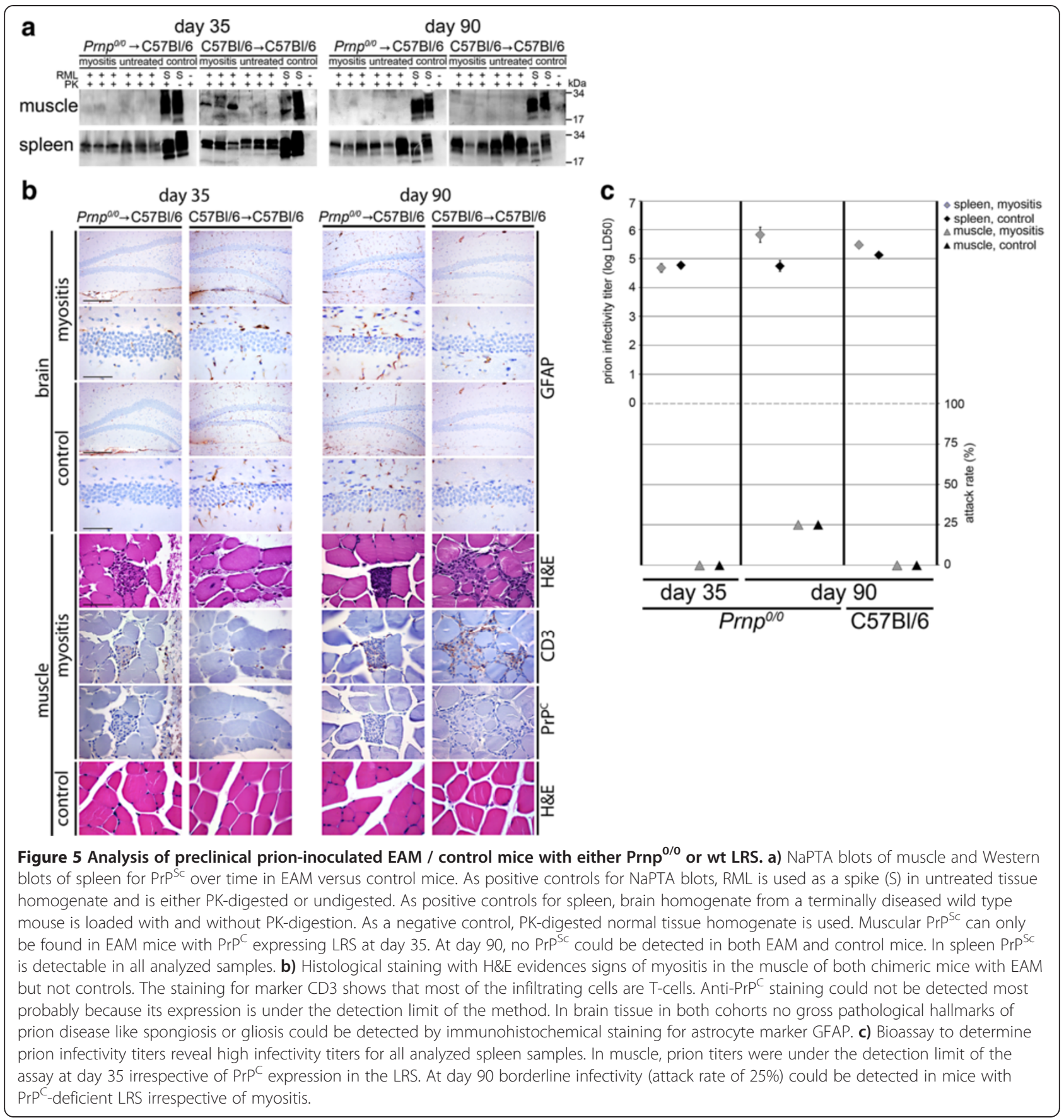

compartment were likely candidates. In order to further investigate the role of $\mathrm{PrP}^{\mathrm{C}}$ in the LRS we generated bone marrow chimeras with a $\operatorname{PrP}^{\mathrm{C}}$-expressing and $\operatorname{PrP}^{\mathrm{C}}$-deficient LRS. Since Prnp ${ }^{0 / 0}$ mice are kept on a $\mathrm{C} 57 \mathrm{Bl} / 6$ background, and the majority of EAM models use a SJL/J background [33], we first had to establish a protocol for the induction of EAM in $\mathrm{C} 57 \mathrm{Bl} / 6$ mice, thus allowing transplantation of syngenic bone marrow.

EAM in C57Bl/6 mice was confirmed by FACS analysis of muscle at 21 days post induction showing increased presence of T-cells (9.1\% CD3-positive cells for EAM; 4.4\% CD3-positive cells for controls, see Table 3). Upon histological analysis, we could observe Tcell dominant perimysial infiltrates in EAM in C57Bl/6 mice (Figure 2). Interestingly, we could not observe MFG-E8-positive FDCs and only a few B-cells.

To study $\operatorname{PrP}^{\mathrm{Sc}}$ accumulation, we lethally irradiated $\mathrm{C} 57 \mathrm{Bl} / 6$ mice and reconstituted their bone marrow with bone marrow of either Prnp ${ }^{0 / 0}$ or $\mathrm{C} 57 \mathrm{Bl} / 6$ mice as a control. The reconstitution efficiency was assessed by 
Table 1 List of primary antibodies

\begin{tabular}{llll}
\hline Name & Specificity & Dilution & Company \\
\hline B220 & B-cells & $1: 400$ & eBioscience \\
CD3 & T-cells & $1: 100$ & Thermo Fisher Scientific \\
GFAP & astrocytes & $1: 200$ & Dako \\
MFG-E8 & follicular dendritic cells & $1: 50$ & BD Bioscience \\
LC3 & autophagy & $1: 200$ & nanoTools \\
POM-1 & PrPC and PrPSc & $1: 1000$ & kindly provided by A. Aguzzi \\
beta-Actin & cytoskeleton & $1: 1000$ & Millipore \\
\hline
\end{tabular}

FACS analysis of blood samples taken three weeks after lethal irradiation (Additional file 3: Figure S3). Afterwards, we induced EAM in $50 \%$ of the mice of both groups $\left(\right.$ Prnp $\left.^{0 / 0} \rightarrow \mathrm{C} 57 \mathrm{Bl} / 6 ; \mathrm{C} 57 \mathrm{Bl} / 6 \rightarrow \mathrm{C} 57 \mathrm{Bl} / 6\right)$ and challenged them with either RML prions or mock at the peak of myositis. Accumulation of $\mathrm{PrP}^{\mathrm{Sc}}$ and infectious prions was investigated by serially sacrificing mice at defined time points (day 35 and 90) and detection of muscular $\mathrm{PrP}^{\mathrm{Sc}}$ loads by NaPTA-precipitation and Western blots. Only in mice with a $\operatorname{PrP}^{C}$-expressing hematopoietic compartment and EAM, we were able to observe significant accumulation of $\mathrm{PrP}^{\mathrm{Sc}}$ in muscle at day 35 (Figure 5a). At day 90, no significant accumulation of $\mathrm{PrP}^{\mathrm{Sc}}$ could be detected in either group. In spleen, $\operatorname{PrP}^{\mathrm{Sc}}$ could be detected at day 35 and day 90 irrespective of the $\mathrm{PrP}^{\mathrm{C}}$ status of the hematopoietic compartment (Figure 5a).

In brain, as expected at this preclinical state of the disease, no spongiform changes or astrogliosis was seen (Figure $5 \mathrm{~b}$ ). In muscle, signs of myositis could be observed in both chimeric cohorts of mice after EAM but not in control mice at day 35 and 90 (Figure 5b). Since myositis is very mild in $\mathrm{C} 57 / \mathrm{Bl} 6$ mouse lines compared to SJL/J mice, immune cells infiltrate singular muscle fibres (first, third and fourth row of pictures) or only the interstitial space (third row of pictures). Most infiltrating cells are T-cells as shown with the immunohistochemical staining of marker CD3. $\mathrm{PrP}^{\mathrm{C}}$ loads are not detectable in muscle tissue by standard $\operatorname{PrP}^{C}$ staining, since expression levels are under the detection limit of this method.

To study the correlation between $\operatorname{PrP}^{\mathrm{Sc}}$ loads and titers of infectious prions, we assayed prion titers of muscle and spleen by bioassay. As shown in Figure 5c, no infectivity was detectable at day 35 whereas at day 90 individual mice came down with prion disease with an attack rate below 50\%, indicating that prion titers in these tissues were at the detection limit of the assay. As expected, in spleen high infectivity titers could be detected at all given time points irrespective of $\mathrm{PrP}^{\mathrm{C}}$ expression in the LRS and myositis.

\section{Discussion}

Although, the central nervous system is the principal site of prion accumulation and replication, and the only site where prion-related tissue damage is seen, $\operatorname{PrP}^{\mathrm{Sc}}$ and prion infectivity can be found in peripheral compartments such as spleen and muscle. Research focusing on mechanisms of prion accumulation in the periphery has yielded important insights into the temporal kinetics and prerequisites of prion accumulation [39]. Presence of $\mathrm{PrP}^{\mathrm{Sc}}$ and prion infectivity in muscle has been highlighted by a number of reports describing its presence in a wide range of instances such as sporadic and variant CJD, BSE, CWD and Scrapie $[12,13,15,29,40,41]$. $\operatorname{PrP}^{\mathrm{Sc}}$ in muscle can be found preclinically in prion-infected rodents and primates [31,42]. Both, nerve fibres and myocytes have been shown to harbour $\mathrm{PrP}^{\mathrm{Sc}}$ within muscle at terminal disease stages [13,15,42], yet in one patient with prion disease and myositis, $\operatorname{PrP}^{\mathrm{Sc}}$ accumulation in muscle was surprisingly high [29]. In summary, the pathophysiological events underlying accumulation of $\operatorname{PrP}^{\mathrm{Sc}}$ and prion infectivity in muscle specifically also in myocytes is poorly understood and it is likely

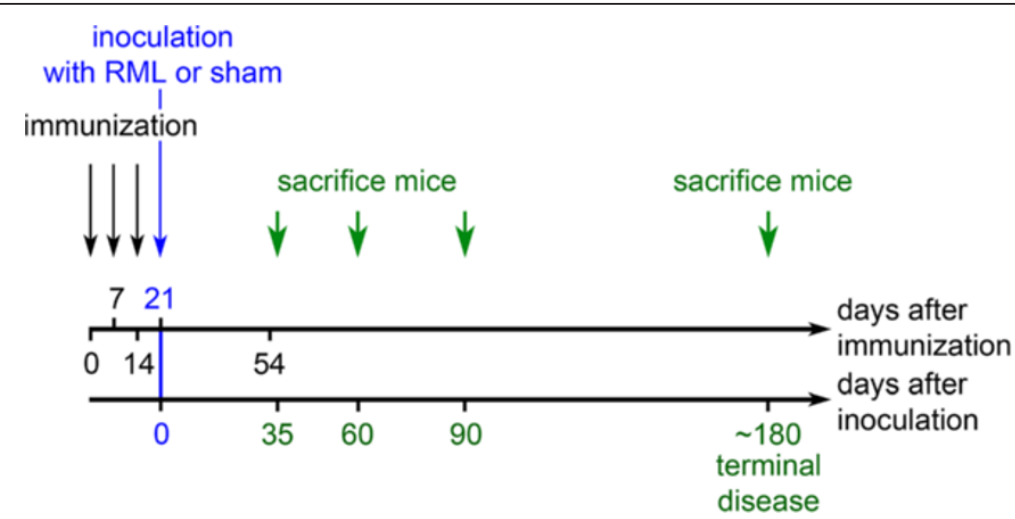

Figure 6 Schedule of the experiments. The upper timeline shows the days after immunization of the mice, whereas the lower timeline displays the time after inoculation with RML or sham. Note that the day of inoculation is set to 0 again in order to calculate the exact days until terminal disease. 
Table 2 FACS analysis of muscle homogenates from $\mathrm{SJ} / \mathrm{J}$ mice with EAE / control at day 21 and 54 after induction of EAE

\begin{tabular}{llll}
\hline Infiltrating cells (in \%) & Control & 21 days & $\mathbf{5 4}$ days \\
\hline T-cells & 5.6 & 50.3 & 21.3 \\
B-cells & 1.2 & 17.3 & 1.4 \\
Other lymphocytes & 5.0 & 6.0 & 3.0 \\
Neutrophile granulocytes & 18.9 & 9.4 & 19.8 \\
\hline
\end{tabular}

Values are the percentages of every immune cell regarding to the total amount of infiltrating cells.

that events predisposing to prion colonization of muscle at terminal disease differ from those at early subclinical time points. Detailed knowledge of the mechanisms controlling prion colonization of muscle may help to explain the role of muscle in neuroinvasion of prions from the periphery to the brain $[43,44]$. Here, we studied the temporal kinetics of $\mathrm{PrP}^{\mathrm{Sc}}$ accumulation and prion titers in two murine EAM models and generated bone marrow chimeras to investigate the role of $\mathrm{PrP}^{\mathrm{C}}$ expression in the lymphoreticular system in myositis.

As expected, in our EAM models, the peak of myositis was reached 21 days following immunization [33]. At this time point, we could observe significantly elevated levels of $\mathrm{PrP}^{\mathrm{C}}$ in muscle by Western blot yet not by immunohistochemical methods. Increased expression of $\mathrm{PrP}^{\mathrm{C}}$ has been linked to a number of diseases of the muscle such as inclusion body myositis, dermato-, and polymyositis $[25,26]$. Our data imply that this increase is transient coinciding with inflammation. Although, presence of myositis did not influence disease kinetics with regard to incubation times until terminal prion disease, we could observe that presence of $\mathrm{PrP}^{\mathrm{Sc}}$ at early subclinical disease is augmented in EAM. Differences were most drastic at days 35 and 60 following prion challenge. Here, we could only detect very low amounts of $\operatorname{PrP}^{\mathrm{Sc}}$ by NaPTA-enhanced Western blotting in controls, whereas mice with EAM showed high (at day 35) and moderate (day 60) $\operatorname{PrP}^{\mathrm{Sc}}$ loads in muscle. Surprisingly, at a time point where the peak of myositis has passed (day 90), $\mathrm{PrP}^{\mathrm{Sc}}$ was completely cleared from muscle. Although, we did not investigate the mechanisms of $\operatorname{PrP}^{\mathrm{Sc}}$ clearance in detail, autophagy may contribute to this as

Table 3 FACS analysis of muscle homogenates from C57BI/6 mice at day 21 after myosin infection or without myositis as a control

\begin{tabular}{lll}
\hline Infiltrating cells (in \%) & Control & 21 days \\
\hline T-cells & 4.4 & 9.1 \\
B-cells & 7.0 & 0.7 \\
Other lymphocytes & 7.1 & 2.1 \\
Neutrophile granulocytes & 17.8 & 37.1 \\
\hline
\end{tabular}

Values are the percentages of every immune cell regarding to the total amount of infiltrating cells. cell culture data [45] and our in vivo data show higher rate of basal autophagy in muscle.

Preclinical $\operatorname{PrP}^{\mathrm{Sc}}$ accumulation in muscle has been demonstrated in a number of instances, yet we are not aware of any study showing clearance of $\mathrm{PrP}^{\mathrm{Sc}}$ from this compartment after prion colonization has been established $[31,42,46]$.

We could observe an uncoupling of $\mathrm{PrP}^{\mathrm{Sc}}$ and prion infectivity in muscle at day 35 and 60, when significant levels of $\mathrm{PrP}^{\mathrm{Sc}}$ in EAM muscle occur in the absence of prion infectivity. Similar findings have recently been reported in the brain [47] and spleen [38]. Thus, our data expand the range of tissues where $\operatorname{PrP}^{\mathrm{Sc}}$ and prion infectivity are not congruent and support the concept that non- $\mathrm{PrP}^{\mathrm{Sc}}$ species considerably contribute to prion infectivity $[47,48]$.

The fact that EAM does not influence incubation time until onset of terminal prion disease is not surprising. Even if absence of $\mathrm{PrP}^{\mathrm{Sc}}$ accumulation or prion infectivity in lymphoid tissue dramatically slows down development of prion disease, augmentation of prion replication even in ectopic sites does not lead to shortening of incubation time until onset of terminal prion disease $[49,50]$. At terminal prion disease, $\operatorname{PrP}^{\mathrm{Sc}}$ and prion infectivity could be observed irrespective of the presence of EAM. This is in line with a wealth of papers detecting $\operatorname{PrP}^{\mathrm{Sc}}$ in muscle $[12,13,29]$. The fact that $\operatorname{PrP}^{\mathrm{Sc}}$ is cleared from muscle and reappears at terminal disease fits to a concept where preclinical $\mathrm{PrP}^{\mathrm{Sc}}$ results from lymphatic spread whereas $\mathrm{PrP}^{\mathrm{Sc}}$ in diseased animals is due to centrifugal spread from the central nervous system $[17,43]$.

It has been suggested that glycosylation patterns of $\mathrm{PrP}^{\mathrm{Sc}}$ differ between muscle and CNS [13]. We could not observe such differences with muscular and brainderived $\mathrm{PrP}^{\mathrm{Sc}}$ showing similar glycosylation patterns.

In the LRS, accumulation of $\operatorname{PrP}^{\mathrm{Sc}}$ and prion infectivity has been associated with FDC networks [20,51]. Since myositis leads to diffuse and not follicular lymphoid infiltrates, we did not find FDC networks, but rather single MFG-E8-positive cells in our EAM muscles. It is questionable if these represent bona fide FDCs or merely MFG-E8-positive macrophages. In either case, accumulation of $\mathrm{PrP}^{\mathrm{Sc}}$ in muscle of EAM mice at early time points occurs in the absence of FDC-networks.

Our experiments with bone marrow chimeras generating mice with a $\operatorname{PrP}^{\mathrm{C}}$-deficient LRS indicate that $\operatorname{PrP}^{\mathrm{C}}$ expression on cells of the LRS is decisive for early, EAMdependent accumulation of $\operatorname{PrP}^{\mathrm{Sc}}$ in muscle. This sets early inflammation-modulated $\mathrm{PrP}^{\mathrm{Sc}}$ accumulation in muscle apart from early $\operatorname{PrP}^{\mathrm{Sc}}$ accumulation in spleen where $\operatorname{PrP}^{\mathrm{Sc}}$ accumulates irrespective of the $\operatorname{PrP}^{C}$ status of the LRS [35]. In the spleen this property has been attributed to FDCs, which are of non-hematopoietic origin and radio-resistant [35]. Thus, it is plausible that in muscle, lack of FDC- 
networks creates a situation, where a $\operatorname{PrP}^{\mathrm{C}}$-expressing LRS is needed for $\operatorname{PrP}^{\mathrm{Sc}}$ accumulation.

These data imply that myocytes are unlikely candidates for accumulation of $\operatorname{PrP}^{\mathrm{Sc}}$ in EAM at early time points. A hypothesis that would accommodate current experimental data, would conceive $\operatorname{PrP}^{\mathrm{Sc}}$ accumulation in muscle as a heterogeneous, disease stage-dependent event. In early disease stages, $\operatorname{PrP}^{\mathrm{Sc}}$ accumulation is driven by cells of hematopoietic origin, whereas at late disease stages, non-hematopoietic cells such as nerve fibres or myocytes represent the main sites for $\operatorname{PrP}^{\mathrm{Sc}}$ accumulation $[13,15,17,18,31,52]$. There have been major concerns regarding biosaftey aspects of muscle biopsy in subclinically prion-diseased patients [12,29]. Although our data indicate that enhanced $\mathrm{PrP}^{\mathrm{Sc}}$-loads in muscle may not be reflected by elevated prion titers it is not possible to interpolate our data from mouse experiments to the human situation and more research efforts are needed to assess biosaftey aspects of muscle biopsy in demented patients.

\section{Conclusions}

Our data show that: (i) myositis positively influences $\mathrm{PrP}^{\mathrm{Sc}}$ accumulation in homogenized muscle tissue at preclinical time points and that a $\operatorname{PrP}^{\mathrm{C}}$-expressing LRS is a prerequisite for this, (ii) $\mathrm{PrP}^{\mathrm{Sc}}$ and prion infectivity are uncoupled in muscle with detectable $\mathrm{PrP}^{\mathrm{Sc}}$ in the absence of prion infectivity at preclinical time points, (iii) muscle, unlike the LRS, has an intrinsically high ability to clear $\mathrm{PrP}^{\mathrm{Sc}}$ once myositis has ceased, possibly involving autophagy.

\section{Additional files}

\section{Additional file 1: Figure S1. Hanging wire test from RML infected} versus untreated mice with and without myositis.

Additional file 2: Figure S2. Analysis of the glycosylation type of $\operatorname{Pr} \mathrm{P}^{\mathrm{Sc}}$ in muscle, brain and spleen.

Additional file 3: Figure S3. Examples of FACS analysis for the expression of $\mathrm{PrP}^{C}$ in blood of $\mathrm{C} 57 \mathrm{BI} / 6, \operatorname{Prnp}^{0 / 0}, \operatorname{tga} 20$ mice and bone marrow chimeras.

\section{Competing interests}

The authors declare that they have no competing interests.

\section{Authors' contributions}

MN: carried out experiments; analysed data; drafted the manuscript. SK: carried out experiments; analysed data; drafted the manuscript. KSch: carried out experiments. KSt: carried out experiments; analysed data. MG: analysed data; drafted the manuscript. All authors read and approved the final manuscript.

\section{Acknowledgements}

This research was supported by grants from the DFG GL 589/2-1 to MG.

\section{Author details}

${ }^{1}$ Institute of Neuropathology, University Medical Center Hamburg-Eppendorf, Hamburg 20246, Germany. ${ }^{2}$ Institute for Neuroimmunology and Clinical MS-Research (inims), Center for Molecular Neurobiology, Hamburg, Germany.
Received: 1 November 2013 Accepted: 1 November 2013

Published: 3 December 2013

\section{References}

1. Aguzzi A, Calella AM: Prions: protein aggregation and infectious diseases. Physiol Rev 2009, 89:1105-1152.

2. Aguzzi A, Polymenidou M: Mammalian prion biology: one century of evolving concepts. Cell 2004, 116:313-327.

3. Cohen FE, Pan KM, Huang Z, Baldwin M, Fletterick RJ, Prusiner SB: Structural clues to prion replication. Science 1994, 264:530-531.

4. Prusiner SB: Prions. Proc Natl Acad Sci USA 1998, 95:13363-13383.

5. Vaccari $G$, Panagiotidis CH, Acin C, Peletto S, Barillet F, Acutis P, Bossers A, Langeveld J, Van Keulen L, Sklaviadis T, Badiola JJ, Andreeoletti O, Groschup $\mathrm{MH}$, Agrimi U, Foster J, Goldmann W: State-of-the-art review of goat TSE in the European Union, with special emphasis on PRNP genetics and epidemiology. Vet Res 2009, 40:48.

6. Williams ES, Young S: Chronic wasting disease of captive mule deer: a spongiform encephalopathy. J Wildl Dis 1980, 16:89-98.

7. Ghani AC: The epidemiology of variant Creutzfeldt-Jakob disease in Europe. Microbes Infect 2002, 4:385-393.

8. Glatzel M, Stoeck K, Seeger H, Luhrs T, Aguzzi A: Human prion diseases: molecular and clinical aspects. Arch Neurol 2005, 62:545-552.

9. Will R: Variant Creutzfeldt-Jakob disease. Folia Neuropathol 2004, 42(Suppl A):77-83.

10. Bruce ME, McConnell I, Will RG, Ironside JW: Detection of variant Creutzfeldt-Jakob disease infectivity in extraneural tissues. Lancet 2001, 358:208-209.

11. Buschmann A, Groschup MH: Highly bovine spongiform encephalopathysensitive transgenic mice confirm the essential restriction of infectivity to the nervous system in clinically diseased cattle. J Infect Dis 2005, 192:934-942.

12. Glatzel M, Abela E, Maissen M, Aguzzi A: Extraneural pathologic prion protein in sporadic Creutzfeldt-Jakob disease. N Engl J Med 2003, 349:1812-1820.

13. Peden $A H$, Ritchie DL, Head MW, Ironside JW: Detection and localization of PrPSc in the skeletal muscle of patients with variant, iatrogenic, and sporadic forms of Creutzfeldt-Jakob disease. Am J Pathol 2006, 168:927-935.

14. Wadsworth JDF, Joiner $\mathrm{S}$, Hill AF, Campbell TA, Desbruslais M, Luthert PJ, Collinge J: Tissue distribution of protease resistant prion protein in variant CJD using a highly sensitive immuno-blotting assay. Lancet 2001, 358:171-180.

15. Andreoletti $\mathrm{O}$, Simon S, Lacroux C, Morel N, Tabouret G, Chabert A, Lugan S, Corbiere F, Ferre P, Foucras G, Laude H, Eychenne F, Grassi J, Schelcher F: PrPSc accumulation in myocytes from sheep incubating natural scrapie. Nat Med 2004, 10:591-593.

16. Angers RC, Browning SR, Seward TS, Sigurdson CJ, Miller MW, Hoover EA, Telling GC: Prions in skeletal muscles of deer with chronic wasting disease. Science 2006, 311:1117.

17. Cardone F, Thomzig A, Schulz-Schaeffer W, Valanzano A, Sbriccoli M, AbdelHaq H, Graziano S, Pritzkow S, Puopolo M, Brown P, Beekes M, Pocchiari M: PrPTSE in muscle-associated lymphatic tissue during the preclinical stage of mice infected orally with bovine spongiform encephalopathy. J Gen Virol 2009, 90:2563-2568.

18. Thomzig A, Kratzel C, Lenz G, Kruger D, Beekes M: Widespread PrP(Sc) accumulation in muscles of hamsters orally infected with scrapie. EMBO Rep 2003, 4:1-4.

19. Glatzel M, Heppner FL, Albers KM, Aguzzi A: Sympathetic innervation of lymphoreticular organs is rate limiting for prion neuroinvasion. Neuron 2001, 31:25-34

20. Montrasio F, Frigg R, Glatzel M, Klein MA, Mackay F, Aguzzi A, Weissmann C: Impaired prion replication in spleens of mice lacking functional follicular dendritic cells. Science 2000, 288:1257-1259.

21. O'Connor T, Frei N, Sponarova J, Schwarz P, Heikenwalder M, Aguzzi A Lymphotoxin, but not TNF, is required for prion invasion of lymph nodes. PLoS Pathog 2012, 8:e1002867.

22. Askanas V, Sarkozi E, Bilak M, Alvarez RB, Engel WK: Human muscle macrophages express beta-amyloid precursor and prion proteins and their mRNAs. Neuroreport 1995, 6:1045-1049.

23. Massimino ML, Ferrari J, Sorgato MC, Bertoli A: Heterogeneous PrPC metabolism in skeletal muscle cells. FEBS Lett 2006, 580:878-884. 
24. Huang $S$, Liang J, Zheng M, Li X, Wang M, Wang P, Vanegas $D$, Wu D, Chakraborty B, Hays AP, Chen K, Chen SG, Booth S, Cohen M, Gambetti P, Kong Q: Inducible overexpression of wild-type prion protein in the muscles leads to a primary myopathy in transgenic mice. Proc Natl Acad Sci USA 2007, 104:6800-6805.

25. Kovacs GG, Kalev O, Gelpi E, Haberler C, Wanschitz J, Strohschneider M, Molnar MJ, Laszlo L, Budka H: The prion protein in human neuromuscular diseases. J Pathol 2004, 204:241-247.

26. Sarkozi E, Askanas V, Engel WK: Abnormal accumulation of prion protein mRNA in muscle fibers of patients with sporadic inclusion-body myositis and hereditary inclusion-body myopathy. The American journal of pathology 1994, 145:1280-1284.

27. Zanusso G, Vattemi G, Ferrari S, Tabaton M, Pecini E, Cavallaro T, Tomelleri G, Filosto M, Tonin P, Nardelli E, Rizzuto N, Monaco S: Increased expression of the normal cellular isoform of prion protein in inclusion-body myositis, inflammatory myopathies and denervation atrophy. Brain Pathol 2001, 11:182-189.

28. Bosque PJ, Ryou C, Telling G, Peretz D, Legname G, DeArmond SJ, Prusiner SB: Prions in skeletal muscle. Proc Natl Acad Sci U S A 2002, 99:3812-3817.

29. Kovacs GG, Lindeck-Pozza E, Chimelli L, Araujo AQ, Gabbai AA, Strobel T, Glatzel M, Aguzzi A, Budka H: Creutzfeldt-Jakob disease and inclusion body myositis: abundant disease-associated prion protein in muscle. Ann Neurol 2004, 55:121-125.

30. Heikenwalder M, Zeller N, Seeger H, Prinz M, Klohn PC, Schwarz P, Ruddle $\mathrm{NH}$, Weissmann C, Aguzzi A: Chronic lymphocytic inflammation specifies the organ tropism of prions. Science 2005, 307:1107-1110.

31. Thomzig A, Schulz-Schaeffer W, Kratzel C, Mai J, Beekes M: Preclinical deposition of pathological prion protein PrPSc in muscles of hamsters orally exposed to scrapie. J Clin Invest 2004, 113:1465-1472.

32. Büeler HR, Fischer $M$, Lang $Y$, Bluethmann $H$, Lipp HP, DeArmond SJ, Prusiner SB, Aguet M, Weissmann C: Normal development and behaviour of mice lacking the neuronal cell-surface PrP protein. Nature 1992, 356:577-582.

33. Suzuki F, Nanki T, Imai T, Kikuchi H, Hirohata S, Kohsaka H, Miyasaka N: Inhibition of CX3CL1 (fractalkine) improves experimental autoimmune myositis in SJL/J mice. J Immunol 2005, 175:6987-6996.

34. Fischer M, Rülicke T, Raeber A, Sailer A, Moser M, Oesch B, Brandner S, Aguzzi A, Weissmann C: Prion protein (PrP) with amino-proximal deletions restoring susceptibility of PrP knockout mice to scrapie. EMBO J 1996, 15:1255-1264.

35. Kaeser PS, Klein MA, Schwarz P, Aguzzi A: Efficient lymphoreticular prion propagation requires $\operatorname{PrP}(c)$ in stromal and hematopoietic cells. J Virol 2001, 75:7097-7106.

36. Prusiner SB, Cochran SP, Groth DF, Downey DE, Bowman KA, Martinez HM: Measurement of the scrapie agent using an incubation time interval assay. Ann Neurol 1982, 11:353-358.

37. Safar J, Prusiner SB: Molecular studies of prion diseases. Prog Brain Res 1998, 117:421-434

38. Krasemann S, Neumann M, Szalay B, Stocking C, Glatzel M: Proteasesensitive prion species in neoplastic spleens of prion-infected mice with uncoupling of PrPSc and prion infectivity. J Gen Virol 2012, 94:453-463.

39. Aguzzi A: Prions and the immune system: a journey through gut, spleen, and nerves. Adv Immunol 2003, 81:123-171.

40. Buschmann A, Gretzschel A, Biacabe AG, Schiebel K, Corona C, Hoffmann C, Eiden M, Baron T, Casalone C, Groschup MH: Atypical BSE in GermanyProof of transmissibility and biochemical characterization. Vet Microbiol 2006, 117(2-4):103-116.

41. Daus ML, Breyer J, Wagenfuehr K, Wemheuer WM, Thomzig A, SchulzSchaeffer WJ, Beekes M: Presence and seeding activity of pathological prion protein (PrP(TSE)) in skeletal muscles of white-tailed deer infected with chronic wasting disease. PLOS ONE 2011, 6:e18345.

42. Krasemann S, Neumann M, Geissen M, Bodemer W, Kaup FJ, SchulzSchaeffer W, Morel N, Aguzzi A, Glatzel M: Preclinical deposition of pathological prion protein in muscle of experimentally infected primates. PLOS ONE 2010, 5:e13906

43. Beekes $M$, McBride PA: The spread of prions through the body in naturally acquired transmissible spongiform encephalopathies. FEBS J 2007, 274:588-605.

44. Kaatz M, Fast C, Ziegler U, Balkema-Buschmann A, Hammerschmidt B, Keller M, Oelschlegel A, Mclntyre L, Groschup MH: Spread of classic BSE prions from the gut via the peripheral nervous system to the brain. Am J Pathol 2012, 181:515-524

45. Lunemann JD, Schmidt J, Dalakas MC, Munz C: Macroautophagy as a pathomechanism in sporadic inclusion body myositis. Autophagy 2007, 3:384-386

46. Thomzig A, Cardone F, Kruger D, Pocchiari M, Brown P, Beekes M: Pathological prion protein in muscles of hamsters and mice infected with rodent-adapted BSE or vCJD. J Gen Virol 2006, 87:251-254.

47. Sandberg MK, Al-Doujaily H, Sharps B, Clarke AR, Collinge J: Prion propagation and toxicity in vivo occur in two distinct mechanistic phases. Nature 2011, 470:540-542.

48. Lewis V, Haigh $\mathrm{CL}$, Masters $\mathrm{CL}$, Hill AF, Lawson VA, Collins SJ: Prion subcellular fractionation reveals infectivity spectrum, with a high titrelow PrPres level disparity. Mol Neurodegener 2012, 7:18.

49. Heikenwalder M, Kurrer MO, Margalith I, Kranich J, Zeller N, Haybaeck J, Polymenidou M, Matter M, Bremer J, Jackson WS, Lindquist S, Sigurdson CJ, Aguzzi A: Lymphotoxin-dependent prion replication in inflammatory stromal cells of granulomas. Immunity 2008, 29:998-1008.

50. Seeger H, Heikenwalder M, Zeller N, Kranich J, Schwarz P, Gaspert A, Seifert $B$, Miele G, Aguzzi A: Coincident scrapie infection and nephritis lead to urinary prion excretion. Science 2005, 310:324-326.

51. Mabbott NA, Mackay F, Minns F, Bruce ME: Temporary inactivation of follicular dendritic cells delays neuroinvasion of scrapie [letter]. Nat Med 2000, 6:719-720

52. Mulcahy ER, Bartz JC, Kincaid AE, Bessen RA: Prion infection of skeletal muscle cells and papillae in the tongue. J Virol 2004, 78:6792-6798.

doi:10.1186/2051-5960-1-78

Cite this article as: Neumann et al:: Myositis facilitates preclinical accumulation of pathological prion protein in muscle. Acta Neuropathologica Communications 2013 1:78.

\section{Submit your next manuscript to BioMed Central and take full advantage of:}

- Convenient online submission

- Thorough peer review

- No space constraints or color figure charges

- Immediate publication on acceptance

- Inclusion in PubMed, CAS, Scopus and Google Scholar

- Research which is freely available for redistribution
C Biomed Central 